Pak. j. sci. ind. res. Ser. A: phys. sci. 2018 61A(3) 149-155

\title{
Hot Corrosion Study of High Velocity Oxy-Fuel (HVOF) Sprayed Coatings on Boiler Tube Steel in Actual Coal Fired Boiler
}

\author{
Varinder Pal Singh Sidhua ${ }^{a}$ Khushdeep Goyal ${ }^{a *}$ and Rakesh Goyal ${ }^{b}$ \\ a Department of Mechanical Engineering, Punjabi University, Patiala, India \\ ${ }^{\mathrm{b}}$ Chitkara University, Rajpura, India \\ (received February 10, 2017; revised May 23, 2018; accepted May 31, 2018)
}

\begin{abstract}
The present study was focused on the effect of high velocity oxy-fuel (HVOF) sprayed 93(WC$\mathrm{Cr}_{3} \mathrm{C}_{2}$ )-7Ni and 86WC-10CO-4C coatings on boiler steel alloys ASME SA213 T22 and ASME SA213 T91 in coal fired boiler environment. To assess the performance of the coatings in actual conditions the coated as well as the uncoated steels were subjected to cyclic exposures, in the superheater zone of a coal fired boiler for 10 cycles at $900{ }^{\circ} \mathrm{C}$. Both the coatings used were observed to be uniform and dense having thickness between 200-250 $\mu \mathrm{m}$. Each cycle consists of $100 \mathrm{~h}$ heating followed by $1 \mathrm{~h}$ cooling at ambient conditions. The thermogravimetric technique was used to establish the kinetics of corrosion. X-ray diffraction (XRD), Scanning Electron Microscopy/Energy Dispersive Spectroscopy (SEM/EDS) techniques were used to analyse corrosion products. The hot corrosion resistance of $86 \mathrm{WC}-10 \mathrm{CO}-4 \mathrm{C}$ coating was found better on ASME SA213 T22 whereas 93(WC-Cr $\left.\mathrm{C}_{2}\right)$-7Ni coating was better on ASME SA213 T22.
\end{abstract}

Keywords: corrosion, boiler steel, degradation, HVOF, coal fired boilers

\section{Introduction}

Hot corrosion has been recognised as a severe problem in boiler tubes of super heater and reheater zone, which may result in premature failure of the tubes. One method to overcome this major problem is the use of thermal spray protective coatings. In past few years, high velocity Oxy-fuel (HVOF) spraying has shown a dramatic influence on the field of thermal sprays. The coating produced is less porous and has higher bond strength than that produced by other methods which is due to the high velocity and high impact of the sprayed powder (Tan et al., 1999). The cost corrosion of metals may rises over $\$ 300$ billion per year (4.2\% GNP) in United States. It is estimated that every year about $40 \%$ of total US steel production goes to replace the corroded parts and products. Although these problems of corrosion can not be wholly remedied but corrosion-related costs can be diminished by more than $30 \%$ with the development and use of better corrosion resistant coatings (Priyantha et al., 2003). Thermal spraying has been considered successful to apply the protective coatings, without disturbing any other properties of the component (Bala et al., 2009; Tillmann et al., 2000). Mostly all the thermally sprayed coatings include splats and splat boundaries. Due to the porosity present at splat boundaries, the coatings are prone to corrosive attack (Usitalo et al., 2004). HVOF coatings provide low

*Author for correspondence: E-mail: khushgoyal@yahoo.com porosity, homogeneous, compact and hard structures with sufficient thickness to stop the advancing of electrolytes (Guilemany et al., 2008). Kawakita et al. (2005) studied that with the addition of molybdenum, a considerable improvement was noticed against corrosion and was most effective on $8 \%$ mass molybdenum. Sidhu et al. (2006) studied the role of high velocity oxyfuel (HVOF) coatings in improving hot corrosion resistance of boiler tube steel (ASTM-SA210 GrA1) and investigated that among $\mathrm{Cr}_{2} \mathrm{C}_{3}-\mathrm{NiCr}, \mathrm{NiCr}$, Wc-Co and stellite- 6 coatings, $\mathrm{NiCr}$ showed maximum whereas $\mathrm{Wc}-\mathrm{Co}$ showed minimum resistance to corrosion. Sidhu et al. (2006a) devised $\mathrm{Ni}-20 \mathrm{Cr}$ wire coating proved effective than $\mathrm{Cr}_{2} \mathrm{C}_{3}-\mathrm{NiCr}$ using Nibased superalloy in environment of molten salt $\mathrm{Na}_{2} \mathrm{SO}_{4}$ $\mathrm{V}_{2} \mathrm{O}_{5}$ at $900{ }^{\circ} \mathrm{C}$. Sidhu et al. (2006b) successfully applied $\mathrm{Ni}-20 \% \mathrm{Cr}$ wire coatings onto $\mathrm{Ni}$ - and $\mathrm{Fe}-$ based superalloys by high velocity oxyfuel process (HVOF) for hot corrosion studies with purpose to characterise the surface and cross-section morphology and confirmed the presence of $\mathrm{Ni}$ as main constituent of $\mathrm{Ni}-20 \% \mathrm{Cr}$ coating. Sidhu (2006) and Prakash (2006) experimentally investigated that plasma sprayed stellite- 6 have higher resistance to erosion-corrosion and T11 coated steel showed the maximum degradation resistance. Sidhu et al. (2006c) investigated that $\mathrm{NiCrBSi}$ coatings were beneficial in lowering the corrosion rate in given environment. Sidhu et al. (2006d) used HVOF (high 
velocity oxy-fuel) process for deposition of $\mathrm{NiCrBSi}$, $\mathrm{Cr}_{2} \mathrm{C}_{3}-\mathrm{NiCr}, \mathrm{Ni}-20 \mathrm{Cr}$ and stellite- 6 coatings on $\mathrm{Fe}-$ based superalloy to study the performance of coatings under cyclic conditions in $\mathrm{Na}_{2} \mathrm{SO}_{4}-60 \% \mathrm{~V}_{2} \mathrm{O}_{5}$ at $900{ }^{\circ} \mathrm{C}$ and noticed that $\mathrm{Ni}-20 \mathrm{Cr}$ coating showed maximum resistance to corrosion. Goyal et al. (2008) studied that $\mathrm{ZrO}_{2}$ was capable of reducing high temperature corrosion in all alloys and was most useful in Superni 75 followed by Superco 605 and slightly in Superfer $800 \mathrm{H}$. Rajasekaran et al. (2004) explained that D-gun spraying minimizes the degradation of the feedstock powder due to lower heat and shorter duration involved in the deposition process. Kamal et al. (2009) investigated that hot-corrosion resistance was better for $\mathrm{Cr}_{3} \mathrm{C}_{2}-\mathrm{NiCr}-$ coated superalloys as compared to the uncoated superalloys in the presence of 75 wt. $\% \mathrm{Na}_{2} \mathrm{SO}_{4}+25$ wt. $\% \mathrm{~K}_{2} \mathrm{SO}_{4}$ film due to the formation of protective oxides of chromium and nickel. Kaushal et al. (2011) revealed that coating had potential to lower the high temperature corrosion using detonation gun spray method to deposit Ni-20Cr onto ASTM A213 TP347H boiler steel. Manpreet (2011) proved $\mathrm{Cr}_{3} \mathrm{C}_{2}-\mathrm{NiCr}$ coating to be highly protective against corrosion. Using detonationgun spray process in which very high particle velocities approaching 4-5 times the speed of sound are achieved. Mishra et al. (2013) reported that aluminium, chromium and yttrium were acting as protective oxides for boiler environmental conditions when the performance of plasma sprayed $\mathrm{Ni}-22 \mathrm{Cr}-10 \mathrm{Al}-1 \mathrm{Y}$ coating on different super alloys such as Superni 75, Superni 600, Superni 718 and Superfer $800 \mathrm{H}$ was investigated. Kaushal et al. (2014) found Detonation sprayed coating to be most protective among all HVOF, detonation gun and cold sprayed $\mathrm{Ni}-20 \mathrm{Cr}$ coatings on $\mathrm{T} 22$ boiler steel tube, he also demonstrated that all three techniques were beneficial in decreasing the corrosion rate of steel. Kumar et al. (2014) noticed that oxidation resistance had been increased by addition of $\mathrm{CeO}_{2}$ in small amount and also found that $\mathrm{Cr}_{3} \mathrm{C}_{2}-\mathrm{NiCr}$ coated and $\mathrm{Cr}_{3} \mathrm{C}_{2}-$ $\mathrm{NiCr}+0.4 \mathrm{wt} . \% \mathrm{CeO}_{2}$ coated Superni 600 had less parabolic rate constant than that of bare Superni 600 .

Current study was planned to compare the behaviour and effect of $93\left(\mathrm{WC}-\mathrm{Cr}_{3} \mathrm{C}_{2}\right)-7 \mathrm{Ni}$ and $86 \mathrm{WC}-10 \mathrm{Co}-4 \mathrm{Cr}$ coatings on ASME SA213 T22 and ASME SA213 T91 materials by assessing its surface and sub surface on heating it at $900{ }^{\circ} \mathrm{C}$ under cyclic conditions.

\section{Materials and Methods}

Substrate materials. For the present study, two Steel based alloys namely ASME SA213 T22 and ASME SA213 T91 were selected as the substrate materials. These steel alloys were obtained from Guru Nanak Dev Thermal Power Plant, Bathinda, Punjab (India). The samples of both alloy steels were cut with the dimensions of $20 \mathrm{~mm} \times 15 \mathrm{~mm} \times 5 \mathrm{~mm}$. Then emery papers of grit sizes $100,150,220,320,600,800$ and 1000 were used to polish the samples. Alumina powder was used for grit blasting of samples. Following two illustrates the chemical composition for ASME SA213 T22 and ASME SA213 T91 boiler tube steels are illustrated in Table 1-2, respectively.

Coating materials. Coatings selected were of two types namely $93\left(\mathrm{WC}-\mathrm{Cr}_{3} \mathrm{C}_{2}\right)-7 \mathrm{Ni}$ and $86 \mathrm{WC}-10 \mathrm{Co}-4 \mathrm{Cr}$. Further, these coatings were deposited onto two steel based alloys using HVOF spray process. Table 3 shows composition and particle size of coating powder.

HVOF spraying. High velocity oxy-fuel thermal spray method was selected for deposition of coatings on two steel alloys at Metallizing Equipment Co. Pvt. Ltd,

Table 1. Chemical composition for ASME SA213 T22 boiler tube steel

\begin{tabular}{lllllllll}
\hline \hline T22 & $\mathrm{C}$ & $\mathrm{Si}$ & $\mathrm{Mn}$ & $\mathrm{S}$ & $\mathrm{P}$ & $\mathrm{Cr}$ & $\mathrm{Mo}$ & $\mathrm{Fe}$ \\
\hline Nominal (\%) & $0.05-0.15$ & 0.5 & $0.30-0.60$ & 0.025 & 0.025 & $1.90-2.60$ & $0.87-1.13$ & Balance \\
Actual (\%) & 0.09 & 0.5 & 0.43 & 0.025 & 0.025 & 2.24 & 0.98 & Balance \\
\hline
\end{tabular}

Table 2. Chemical composition for ASME SA213 T91 boiler tube steel

\begin{tabular}{llllllllllll}
\hline \hline T91 & $\mathrm{C}$ & $\mathrm{Si}$ & $\mathrm{Mn}$ & $\mathrm{S}$ & $\mathrm{P}$ & $\mathrm{Cr}$ & $\mathrm{Mo}$ & $\mathrm{Ni}$ & $\mathrm{V}$ & $\mathrm{Al}$ & $\mathrm{Fe}$ \\
\hline Nominal (\%) & $0.07-0.14$ & $0.20-0.50$ & $0.30-0.60$ & 0.02 & 0.02 & $8.0-9.5$ & $0.85-1.05$ & 0.4 & $0.18-0.25$ & 0.015 & Balance \\
Actual (\%) & 0.11 & 0.33 & 0.41 & 0.02 & 0.02 & 8.8 & 0.93 & 0.4 & 0.21 & 0.015 & Balance \\
\hline \hline
\end{tabular}


Jodhpur, Rajasthan (India). Commercial HVOF (HIPOJET-2100) apparatus functioning with oxygen and liquid petroleum gas (LPG) as input gases, was used. Table 4 shows spray parameters.

The coatings have been designated as follows: $\mathrm{C} 1 \mathrm{~T} 22$ : 93( $\left(\mathrm{WC}-\mathrm{Cr}_{3} \mathrm{C}_{2}\right)-7 \mathrm{Ni}$ coated T22 specimen, C1 T91:

Table 3. Composition and particle size of coating powder (supplied by MEC Jodhpur)

\begin{tabular}{lll}
\hline \hline Coating powder & Composition (wt\%) & $\begin{array}{l}\text { Particle size } \\
(\mu \mathrm{m})\end{array}$ \\
\hline 93(WC-Cr$\left.{ }_{3} \mathrm{C}_{2}\right)-7 \mathrm{Ni}$ & $\mathrm{WC}(73), \mathrm{Cr}_{3} \mathrm{C}_{2}(20), \mathrm{Ni}(7)$ & $-45+15$ \\
86WC-10Co-4Cr & $\mathrm{WC}(86), \mathrm{Co}(10), \mathrm{Cr}(4)$ & $-45+15$ \\
\hline \hline
\end{tabular}
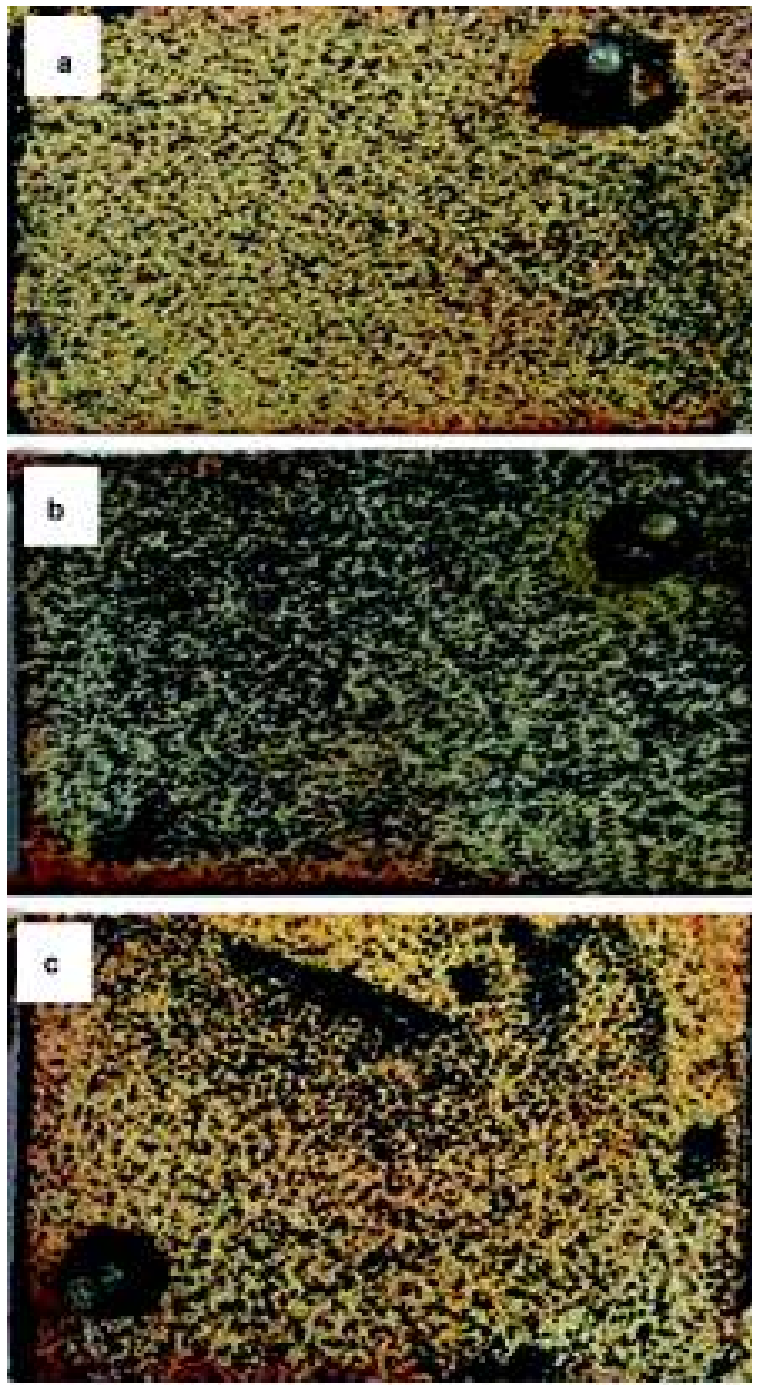

93( $\left(\mathrm{WC}-\mathrm{Cr}_{3} \mathrm{C}_{2}\right)-7 \mathrm{Ni}$ coated $\mathrm{T} 91$ specimen, C2 T22: 86WC-10Co-4Cr coated T22 specimen, C2 T91: 86WC10Co-4Cr coated T91 specimen.

Table 4. Spray parameters employed during HVOF spray process

\begin{tabular}{ll}
\hline \hline Parameters & Values \\
\hline Oxygen flow rate & $250 \mathrm{LPM}$ \\
Fuel (LPG) flow rate & $60 \mathrm{LPM}$ \\
Air flow rate & $900 \mathrm{LPM}$ \\
Spray distance & $200 \mathrm{~mm}$ \\
Fuel pressure & $6 \mathrm{~kg} / \mathrm{cm}^{2}$ \\
Oxygen pressure & $8 \mathrm{~kg} / \mathrm{cm}^{2}$ \\
Air pressure & $6 \mathrm{~kg} / \mathrm{cm}^{2}$ \\
\hline \hline
\end{tabular}
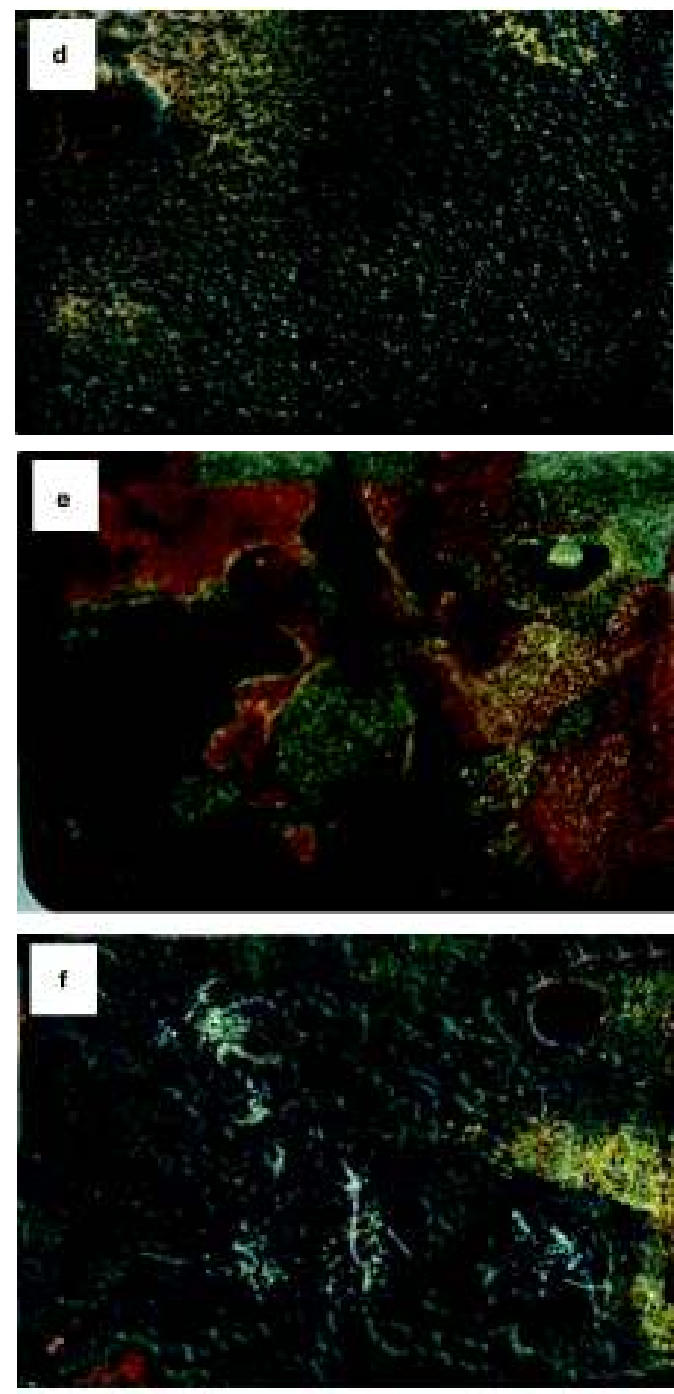

Fig. 1(a-f). Macrographs of the HVOF sprayed T22 and T91 specimen (a) C1 T22 (b) C1 T91, (c) C2 T22, (d) C2 T91, (e) T22 uncoated and (f) T91 uncoated. 
Studies in coal fired boilers. The uncoated as well as HVOF coated steel alloy specimens were examined in an actual boiler environment in the middle zone of platen superheater of the Stage-II boiler of Guru Nanak Dev Thermal Plant, Bathinda, Punjab (India). Nichrome wire was passed through a predrilled hole of $1 \mathrm{~mm}$ among all the samples, then these samples were inserted through the soot blower dummy points at $34.5-\mathrm{m}$ height from the base of the boiler and these specimens were exposed for 10 cycles to combustion environment. Each cycle consisted of $100 \mathrm{~h}$ heating, followed by $1 \mathrm{~h}$ cooling at ambient conditions. The temperature was measured at regular intervals and the average temperature during the study was observed to be about $900^{\circ} \mathrm{C}$ with variation of $\pm 10^{\circ} \mathrm{C}$. The specimens were visually observed for any change on surface and weight of specimens was measured subsequently at the end of each cycle.

The samples were examined by X-ray diffraction (XRD), Scanning Electron Microscopy/Energy Dispersive Spectroscopy (SEM/EDS) after the cyclic studies. The hot corrosion behaviour of bare and HVOF coated ASME SA213 T22 and ASME SA213 T91 in the given environment was assessed by measuring the thermogravimetric data, metal thickness loss corresponding to the corrosion scale development and the depth of internal corrosion attack after $1000 \mathrm{~h}$ exposure under cyclic conditions.

\section{Results and Discussion}

Visual examination of uncoated and HVOF coated T22 and T91. The macrographs for uncoated steel based alloy and HVOF sprayed $93\left(\mathrm{WC}-\mathrm{Cr}_{3} \mathrm{C}_{2}\right)-7 \mathrm{Ni}$ and $86 \mathrm{WC}-10 \mathrm{Co}-4 \mathrm{Cr}$ coatings on T22 and T91 after 1000 $\mathrm{h}$ exposure to the superheater zone of the coal fired boiler are depicted in Fig. 1.

Weight change measurements. Weight change measurements of bare, $93\left(\mathrm{WC}-\mathrm{Cr}_{3} \mathrm{C}_{2}\right)-7 \mathrm{Ni}$ coated and 86WC-10CO-4Cr coated of both ASME SA213 T22 and ASME SA213 T91 subjected to cyclic oxidation for 10 cycles at $900{ }^{\circ} \mathrm{C}$ are noticed. Weight gained by $86 \mathrm{WC}-10 \mathrm{CO}-4 \mathrm{Cr}$ coated T22 was minimum and weight gained by bare T22 steel alloys was maximum. Figure 2 shows the graph between weight change per unit area and number of cycles for both the uncoated and HVOF coated (T22, T91) samples subjected to $1000 \mathrm{~h}$ cyclic exposure to low temperature superheater zone of coal fired boiler at $900{ }^{\circ} \mathrm{C}$. Figure 3 shows the column graph for weight gained per unit area of uncoated and coated samples (where $\mathrm{C} 1=93\left(\mathrm{WC}-\mathrm{Cr}_{3} \mathrm{C}_{2}\right)-7 \mathrm{Ni}, \mathrm{C} 2=86 \mathrm{WC}-$ $10 \mathrm{CO}-4 \mathrm{Cr}$ ).

$\mathrm{X}$-ray diffraction. X-ray diffraction analysis patterns for both corroded uncoated and HVOF coated samples are shown in Fig. 4. Uncoated specimen after introduction to boiler temperature for 10 cycles indicated the presence of $\mathrm{Fe}_{2} \mathrm{O}_{3}$. The $93\left(\mathrm{WC}-\mathrm{Cr}_{3} \mathrm{C}_{2}\right)-7 \mathrm{Ni}$ coated T22 and T91 steel alloys show the existence of $\alpha-\mathrm{WC}$, $\gamma-\mathrm{NiCr}$ and $\beta-\mathrm{Cr}_{3} \mathrm{C}_{2}$ on their surface. In case of $86 \mathrm{WC}$ $10 \mathrm{CO}-4 \mathrm{Cr}$ coated $\mathrm{T} 22$ and $\mathrm{T} 91$ specimen, the surface scale indicated the occurrence of $\alpha-\mathrm{WC}, \beta-\mathrm{W}_{2} \mathrm{C}$.

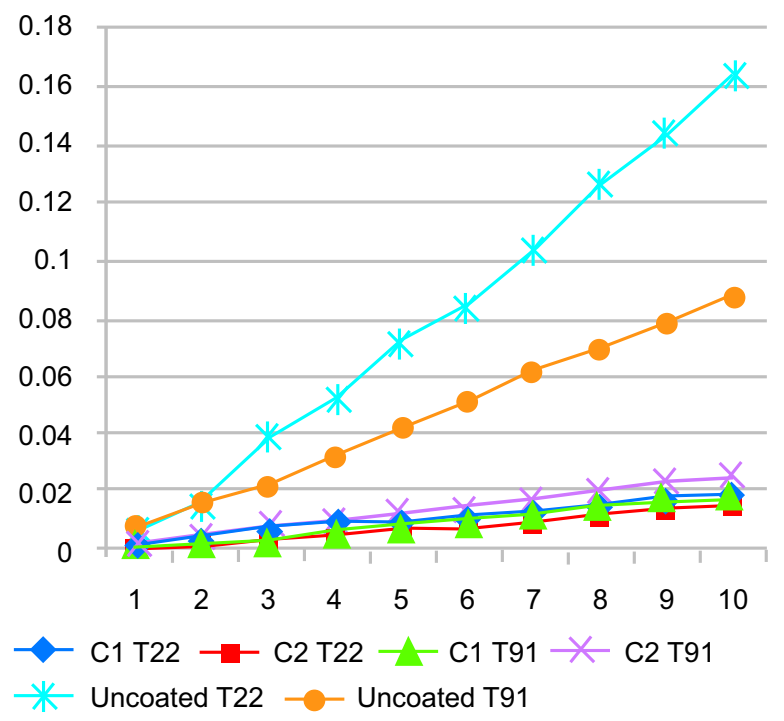

Fig. 2. Weight change vs cycles plots for the uncoated and HVOF coated (T22, T91) samples subjected to $1000 \mathrm{~h}$ cyclic exposure to low temperature superheater zone of coal fired boiler at $900{ }^{\circ} \mathrm{C}$.

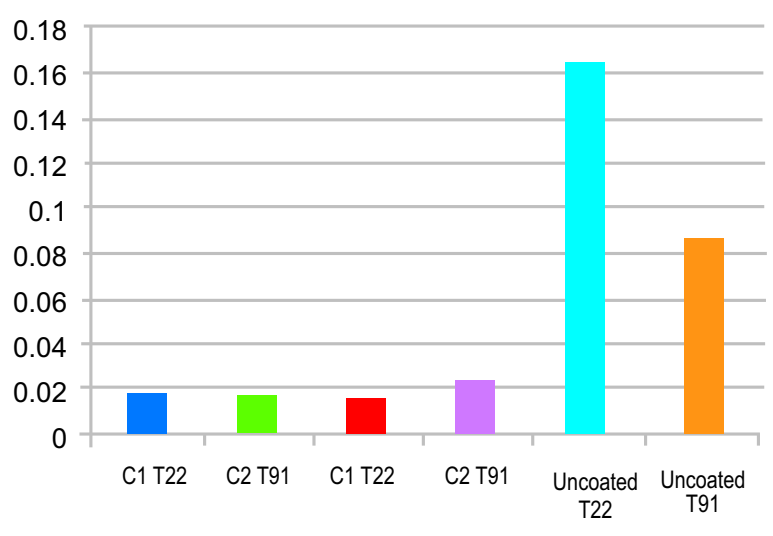

Fig. 3. Column chart of weight gain per unit area for uncoated and HVOF coated samples. 


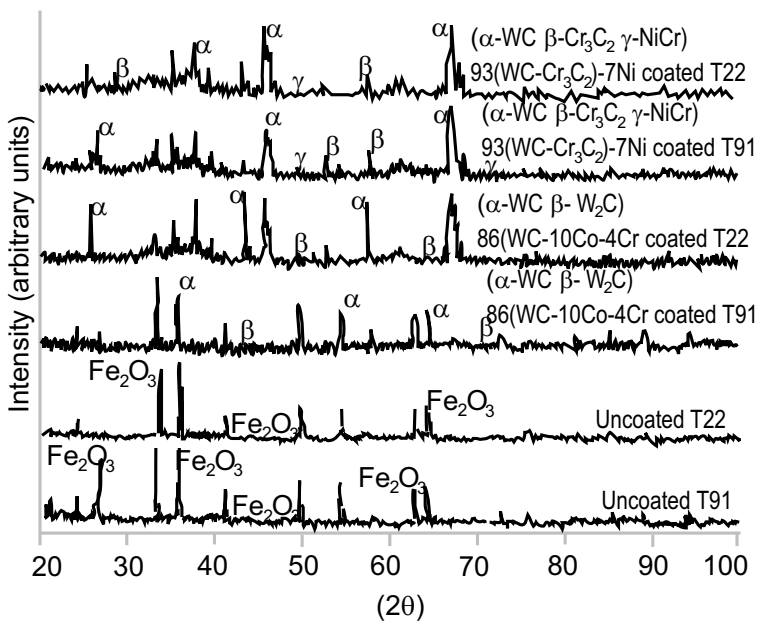

Fig. 4. X-ray diffraction of T22 and T91 of uncoated and HVOF coated specimens.

SEM/EDS. In scanning electron microscopy the pictures show the existence of carbides and oxides. Additionally it has been proved by energy dispersive spectroscopy (EDS) by identifying the carbon and oxygen and also proved by X-ray diffraction (XRD). Scanning electron microscopy (SEM) images of both uncoated as well as coated ASME SA213 T22 and ASME SA213 T91 alloy steel specimens are shown in Fig. 5.

\section{Conclusion}

- All the coatings on both the steel alloys were uniform and dense with thickness of coatings was between $200-250 \mu \mathrm{m}$.

- HVOF spraying process has been effectively employed for depositing $93\left(\mathrm{WC}-\mathrm{Cr}_{3} \mathrm{C}_{2}\right)-7 \mathrm{Ni}$ and 86WC-10CO-4Cr coatings on steel alloys namely ASME SA213 T22 and ASME SA213 T91.

- All the coatings on both steel alloys namely ASME SA213 T22 and ASME SA213 T91 used in present studies have provided resistance to corrosion in coal fired boiler environment in superheater zone when exposed for 10 cycles at $900{ }^{\circ} \mathrm{C}$ and have shown the following order of resistance to corrosion.

$86 \mathrm{WC}-10 \mathrm{CO}-4 \mathrm{Cr}$ coated $\mathrm{T} 22>93\left(\mathrm{WC}-\mathrm{Cr}_{3} \mathrm{C}_{2}\right)-7 \mathrm{Ni}$ coated $\mathrm{T} 91>93\left(\mathrm{WC}-\mathrm{Cr}_{3} \mathrm{C}_{2}\right)-7 \mathrm{Ni}$ coated $\mathrm{T} 22>$ $86 \mathrm{WC}-10 \mathrm{CO}-4 \mathrm{Cr}$ coated T91.

- Among all uncoated and coated samples, the uncoated samples have shown least resistance to corrosion. But ASME SA213 T22 has shown minimum resistance to corrosion.
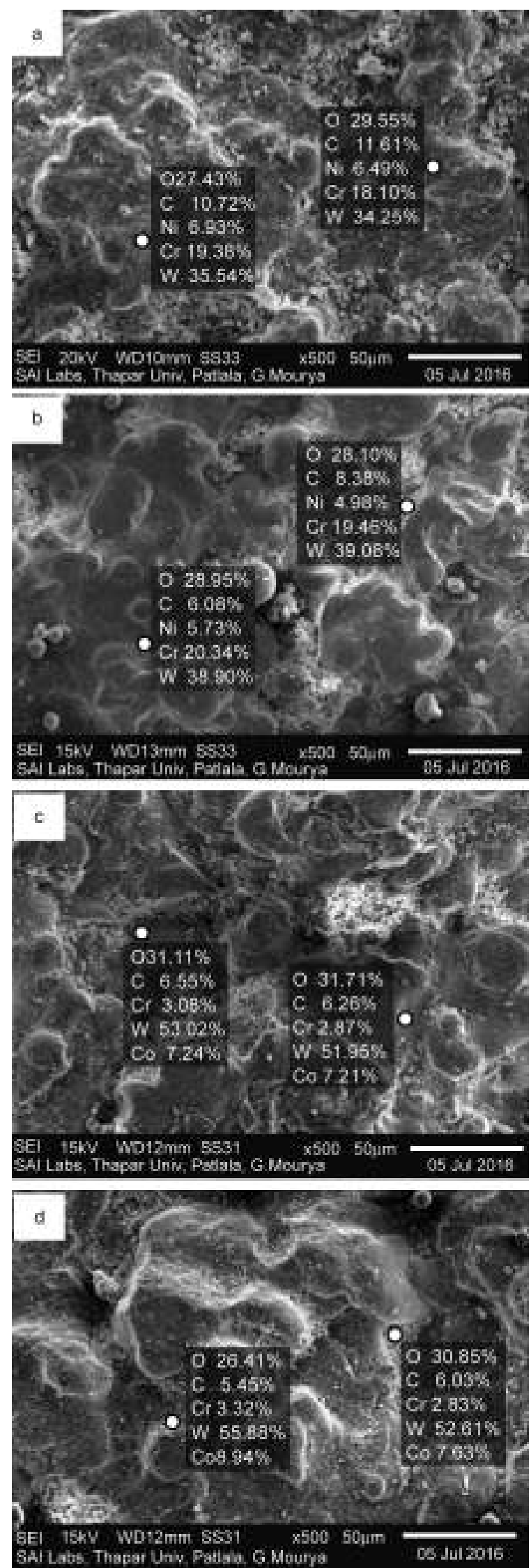

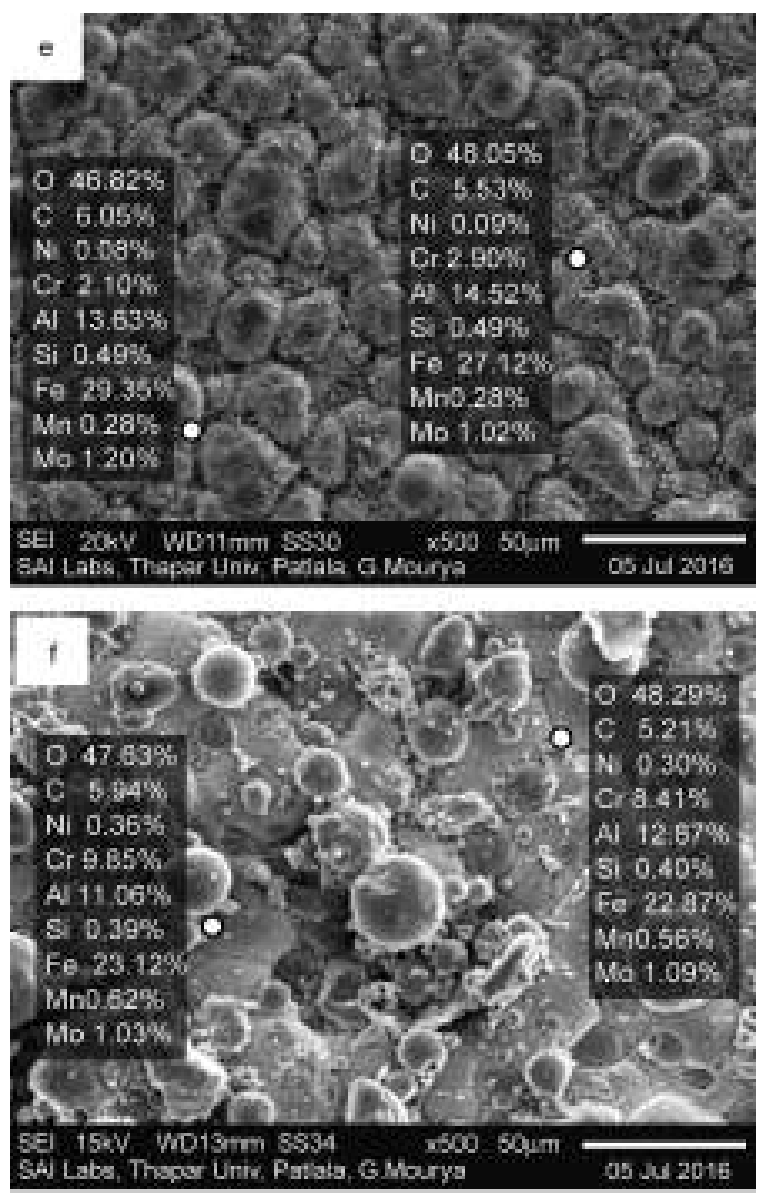

Fig. 5(a-f). Surface morphology and EDS analysis after 10 cycles in superheater of boiler at $900{ }^{\circ} \mathrm{C}$ for T22 (a) $93\left(\mathrm{WC}-\mathrm{Cr}_{3} \mathrm{C}_{2}\right.$ )$7 \mathrm{Ni}$ coated $\mathrm{T} 22$ (b) $93\left(\mathrm{WC}-\mathrm{Cr}_{3} \mathrm{C}_{2}\right)-7 \mathrm{Ni}$ coated T91, (c) 86WC-10Co-4Cr coated T22, (d) $86 \mathrm{WC}-10 \mathrm{Co}-4 \mathrm{Cr}$ coated T91 (e) T22 uncoated (f) T91 uncoated.

- The improved corrosion resistance of 86WC-10CO4Cr coated on ASME SA213 T22 steel alloys may be due to the formation of thin band of oxides of nickel, chromium and carbides of tungsten.

\section{References}

Bala, N., Singh, H., Prakash, S. 2009. High-temperature oxidation studies of cold-sprayed $\mathrm{Ni}-20 \mathrm{Cr}$ and $\mathrm{Ni}-50 \mathrm{Cr}$ coatings on SAE 213-T22 boiler steel. Applied Surface Science, 255: 6862-6869.

Goyal, G., Singh, H., Prakash, S. 2008. Effect of superficially applied $\mathrm{ZrO}_{2}$ inhibitor on the high temperature corrosion performance of some Fe-, Co- and Ni-base superalloys. Applied Surface
Science, 254: 6653-6661.

Guilemany, J.M., Torrell, M., Miguel, J.R. 2008. Study of the HVOF Ni-based coatings corrosion resistance applied on municipal solid-waste incinerators. Journal of Thermal Spray Technology, 17: 254262.

Kamal, S., Jayaganthan, R., Prakash, S. 2009. Evaluation of cyclic hot corrosion behaviour of detonation gun sprayed $\mathrm{Cr}_{3} \mathrm{C}_{2}-25 \% \mathrm{NiCr}$ coatings on nickeland iron-based superalloys. Surface \& Coatings Technology, 203: 1004-1013.

Kaushal, G., Bala, N., Kaur, N., Prakash, S. 2014. Comparative high-temperature corrosion behaviour of Ni-20Cr coatings on T22 boiler steel produced by HVOF, D-gun, and cold spraying. Metallurgical and Materials Transactions A, 45A: 395-410.

Kaushal, G., Singh, H., Prakash, S. 2011. Surface engineering by detonation-gun spray coating of $347 \mathrm{H}$ boiler steel to enhance its high temperature corrosion resistance. Materials at High Temperatures, 28: 1-11.

Kawakita, J., Kuroda, S., Fukushima, T., Kodama, T. 2005. Improvement of corrosion resistance of high velocity oxy-fuel sprayed stainless steel coatings by addition of molybdenum. Journal of Thermal Spray Technology, 14: 224-230.

Kumara, S., Mudgal, D., Singh, S., Prakash, S. 2014. Effect of $\mathrm{CeO}_{2}$ in $\mathrm{Cr}_{3} \mathrm{C}_{2}-\mathrm{NiCr}$ coating on superni 600 at high temperature. Procedia Materials Science, 6: 939-949.

Manpreet, K., Singh, H., Prakash, S. 2011. Surface engineering analysis of detonation-gun sprayed $\mathrm{Cr}_{3} \mathrm{C}_{2}-\mathrm{NiCr}$ coating under high-temperature oxidation and oxidation-erosion environments. Surface and Coatings Technology, 206: 530-541.

Mishra, S.B., Chandra, K., Prakash, S. 2013. Erosioncorrosion performance of NiCrAlY coating produced by plasma spray process in a coal-fired thermal power plant. Surface and Coatings Technology, 216: 23-34.

Priyantha, N., Jayaweera, P., Sanjurjo, A., Lau, K., Lu, F., Krist, K. 2003. Corrosion-resistant metallic coatings for applications in highly aggressive environments. Surface and Coatings Technology, 163-164: 31-36.

Rajasekaran, B., Raman, G.S., Joshi, S.V., Sundararajan, G. 2009. Effect of grinding on plain fatigue and fretting fatigue behaviour of detonation gun sprayed $\mathrm{Cu}-\mathrm{Ni}-\mathrm{in}$ coating on $\mathrm{Al}-\mathrm{Mg}-\mathrm{Si}$ alloy. International 
Journal of Fatigue, 31: 791-796.

Sidhu, B.S., Prakash, S. 2006. Erosion-corrosion of plasma as sprayed and laser remelted stellite- 6 coatings in a coal fired boiler. Wear, 260: 1035 1044.

Sidhu, S.H., Sidhu, B.S., Prakash, S. 2006. The role of HVOF coatings in improving hot corrosion resistance of ASTM-SA210 GrA1 steel in the presence of $\mathrm{Na}_{2} \mathrm{SO}_{4}-\mathrm{V}_{2} \mathrm{O}_{5}$ salt deposits. Surface \& Coatings Technology, 200: 5386-5394.

Sidhu, T.S., Prakash, S., Agrawal, R.D. 2006a. Hot corrosion studies of HVOF sprayed $\mathrm{Cr} 3 \mathrm{C} 2-\mathrm{NiCr}$ and $\mathrm{Ni}-20 \mathrm{Cr}$ coatings on nickel-based superalloy at $900{ }^{\circ} \mathrm{C}$. Surface \& Coatings Technology, 201: 792-800.

Sidhu, T.S., Prakash, S., Agrawal, R.D. 2006b. Characterisation of NiCr wire coating on Ni- and Fe-based superalloys by the HVOF process. Surface \& Coatings Technology, 200: 5542-5549.

Sidhu, T.S., Prakash, S., Agrawal, R.D. 2006c. Characterisations of HVOF sprayed NiCrBSi coatings on $\mathrm{Ni}$ - and Fe-based superalloys and evaluation of cyclic oxidation behaviour of some Ni-based superalloys in molten salt environment. Thin Solid Films, 515: 95-105.

Sidhu, T.S., Prakash, S., Agrawal, R.D. 2006d. Performance of high velocity oxyfuel-sprayed coatings on an fe-based superalloy in $\mathrm{Na}_{2} \mathrm{SO}_{4}-60 \% \mathrm{~V}_{2} \mathrm{O}_{5}$ environment at $900{ }^{\circ} \mathrm{C}$ PartII: Hot corrosion behaviour of the coatings. Journal of Materials Engineering and Performance, 15: 130-138.

Tan, J.C., Looney, L., Hashmi, M.S.J. 1999. Component Repair Using HVOF Thermal Spraying. Journal of Materials Processing Technology, 92-93: 203-208.

Tillmann, W., Vogli, E., Baumann, I., Kopp, G., Weihs, C. 2010. Desirability-based multi-criteria optimization of HVOF spray experiments to manufacture fine structured wear-resistant $75 \mathrm{Cr} 3 \mathrm{C} 2-25(\mathrm{NiCr} 20)$ coatings. Journal of Thermal Spray Technology, 19: 392-408.

Uusitalo, M.A., Vuoristo, P.M.J., Mantyla, T.A. 2004. High temperature corrosion of coatings and boiler steels below chlorine-containing salt deposits. Corrosion Science, 46: 1311-1331. 